\title{
First Full Length Genome Sequence of Bean Common Mosaic Necrosis Virus (BCMNV) Isolated from Common Bean in Western Kenya
}

\author{
Mangeni Bonphace Collins ${ }^{1, ~ *}$, Were Hassan Karakacha ${ }^{2}$, Mukoye Benard ${ }^{3}$, Ndong’a Milicent ${ }^{1}$ \\ ${ }^{1}$ Department of Biological Sciences, Masinde Muliro University of Science and Technology, Kakamega, Kenya \\ ${ }^{2}$ Department of Agriculture and Land Use Management, Masinde Muliro University of Science and Technology, Kakamega, Kenya \\ ${ }^{3}$ Kenya Plant Health Inspectorate Service (KEPHIS), KEPHIS Headquarters, Nairobi, Kenya
}

Email address:

bmangeni@mmust.ac.ke (M. B. Collins), hwere@mmust.ac.ke (W. H. Karakacha), bmukoye@kephis.org (M. Benard),

mndonga@mmust.ac.ke (N. Millicent)

${ }^{*}$ Corresponding author

\section{To cite this article:}

Mangeni Bonphace Collins, Were Hassan Karakacha, Mukoye Benard, Ndong'a Milicent. First Full Length Genome Sequence of Bean Common Mosaic Necrosis Virus (BCMNV) Isolated from Common Bean in Western Kenya. International Journal of Genetics and Genomics. Vol. 7, No. 4, 2019, pp. 132-135. doi: 10.11648/j.ijgg.20190704.18

Received: October 23, 2019; Accepted: November 22, 2019; Published: December 2, 2019

\begin{abstract}
Bean common mosaic necrosis virus (BCMNV) is one of the most common and most destructive viruses of common bean and can cause a yield loss as high as $100 \%$. The common bean (Phaseolus vulgaris $\mathrm{L}$ ) is an important legume crop for food and cash in Kenya. In Kenya, there is inadequate documentation on the strains of the virus infecting common bean. This information is crucial in devising control measures. This study therefore, sought to characterize BCMNV isolates from western Kenya. Leafy samples showing virus-like symptoms were collected and analysed by Enzyme linked immunosorbent Assay (ELISA) and or next generation sequencing (NGS). Extraction of total RNA from ELISA positive samples was done using RNeasy Plant Mini Kit and NGS carried out following Illumina protocol to determine diversity of the virus. NGS data was trimmed and the sequence reads assembled into contigs, which were analyzed against virus sequence database. Phylogenetic analyses and comparisons were performed using MEGA7 program. The first complete genome sequence of Bean common mosaic virus (BCMNV) is reported from a Kenyan isolate. NGS technology revealed full-length sequence of BCMNV from an isolate BG 12 from Bungoma County with a genome of $9584 \mathrm{nt}$ in length. Phylogenetic analysis of full-length sequences available through the Genbank clustered the isolate with the Tanzanian isolate strain TN-1 and two USA isolates, TN1a and NL-3K.
\end{abstract}

Keywords: BCMNV, Genome, Sequence, Kenya

\section{Introduction}

Bean common mosaic necrosis virus (BCMNV) belongs to the Family Potyviridae, genus Potyvirus, which is the largest of the eight genera currently assigned to the family by the International Committee on Taxonomy of Viruses [1]. The virus infects legumes in many parts of the world and causes significant yield losses of up to $100 \%$ [2]. BCMNV is seed-borne and its spread in the field by aphids in a non-persistent manner. BCMNV is monopartite, single stranded positive-sense RNA virus with flexuous rod-shaped virions that are $750 \mathrm{~nm}$ in length with a diameter of $11-13 \mathrm{~nm}$ [3]. The virion RNA molecule is approximately $10 \mathrm{~kb}$ long with a 30 -terminal polyA tail [4]. The genome has the 5' end covalently linked to a virus-encoded protein (VPg) and the 3' end polyadenylated. An important property of potyviruses is that 10 out of 11 proteins that they encode are derived from a single polyprotein precursor [5]. The other protein, P3N-PIPO, is separately synthesized from a small ORF [6]. Discovery of BCMNV began in 1917 when its close member BCMV was identified and named variously as Bean virus 1 , Bean mosaic virus, and Phaseolus virus 1 [7]. Until 1943, it was presumed that BCMV strains were identical pathogenically since the 
originally identified BCMV isolate was lost [8]. Differential symptoms on ten bean cultivars identified the distinct pathogenic groups of BCMV in 1943. The results were utilised in taxonomy classifying the strains into the seven pathogenic groups (I-VII). BCMV starins were later categorized to $\mathrm{A}$ and $\mathrm{B}$ serotypes based on differential responses of various bean cultivars to infection, coat protein (CP) serology and proteolytic digests of CPs analysis [9]. Berger et al. (1997) [10] later reclassified serotypes A and B as BCMNV and BCMV respectively. BCMNV has five identified strains i.e. TN-1, NL-8, NL-3, NL-3K and NL-5 [11]. Strains of BCMV are many including very distinct viruses, such as Azuki bean mosaic virus (AzMV), Blackeye cowpea mosaic virus (BICMV), Peanut stripe virus (PStV) and (Dendrobium mosaic virus (DeMV) [12]. By 2015, there were $22 \mathrm{BCMV}$ full length genome sequences and $9 \mathrm{BCMNV}$ full length genome sequences available through NCBI currently [13]. $3^{0}$-UTR sequence data and CP genes have been used to group BCMV isolates [14]. BCMNV is transmitted by seeds up to $83 \%$ in Phaseolus vulgaris L and by several aphid species [15]. Aphid species including; Bean aphid (Aphis fabae), Cowpea aphid (Aphis craccivora), Pea aphid (Acyrthosiphon pisum), Green peach aphid (Myzus persicae) and Potato aphid (Macrosiphum euphobiae) are known to transmit the virus [16]. Seed transmission occurs irregularly and may majorly depend on age of the plant at the time of infection, virus strain and bean variety. Aphid transmission occurs non-persistently and spread the virus on short distances as compared to seed transmission that may spread viruses around the world [17]. Infected plants are produced even at low seed transmission and at most suitable time for vector transmission may result in spreading the virus in the field very fast [18]. Systemically infected plants prior to flowering may produce infected seeds and this may account for the higher transmission rates [19]. Seed transmission is minimal or may not occur if the infection occurs after flowering [20]. Phaseolus species form the natural hosts of BCMNV mainly restricted to P. vulgaris [21]. However, the virus has been isolated naturally from other leguminous species including Phaseolus lunatus, Phaseolus acutifolius, Arachis hypogaea, Cajanus cajan, Bauhinia purpurea, Centrosema pubescens, Chenopodium quinoa, Crotalaria juncea, Crotalaria incana, Crotalaria spectabilis, Cucumis sativus, Lupinus angustifolius, Glycine max, Lablab purpureus, Lupinus albus, Lupinus luteus, Macroptilium lathyroides, Macroptilium atropurpureum, Medicago sativa, Melilotus alba, Trifolium incarnatum, Pisum sativum, Vicia sativa, Vigna subterranea, Rhynchosia minima, Vigna unguiculata, Vigna vexillata, Sesbania herbacea, Trifolium pretense, Trifolium repens, Trifolium subterraneum, Trifolium hybridum, Vicia villosa and Vigna radiate.

\section{Materials and Methods}

During the short rain season in September to October 2016 and the long rain season in April to June 2017, surveys were conducted in six agro ecological zones that are in major common bean growing counties of Western Kenya. Symptomatic and asymptomatic leaf samples showing virus-like symptoms of mosaic, leaf distortion, downward curling, mottling, vein necrosis, local lesions, stunting or a combination of these were collected Serological and molecular analysis.

Triple Antibody Sandwich (TAS) ELISA was conducted following manufacturers (DSMZ, Germany) protocol. 65 out of 240 of the samples collected, tested positive for BCMNV. Eleven TAS ELISA positive samples were further analysed by next generation sequencing.

Total RNA was extracted from semi-purified virions using All Prep RNA Mini Kit (Qiagen RNAeasy) according to the manufacturers' recommendation. Before starting, $10 \mu \mathrm{l}$ Mercaptoethanol was added to Buffer RLT or RLC. $44 \mathrm{ml}$ ethanol was added to concentrated Buffer RPE. 100mg ca. plant material $(3 \mathrm{~cm} \times 3 \mathrm{~cm})$ was ground in a sample bag in liquid $\mathrm{N}_{2}$ and 450-1000 $\mu \mathrm{l}$ RLT or RLC added and grinded again. $450 \mu \mathrm{l}$ of this lysate was transferred to a Qiashredder and centrifuged 2' at full speed. The flow-through was transferred to a new tube without disturbing the cell-debris pellet. 0.5 volume $(225 \mu \mathrm{l})$ abs. ETOH was added and mixed by pipetting. The sample including any precipitate that may have formed $(650 \mu \mathrm{l})$ was transferred to an RNeasy spin column, Centrifuged $15 \mathrm{~s}$ at $10000 \mathrm{rpm}$ and the flow-through discarded. $700 \mu \mathrm{l}$ buffer RWE was added and centrifuged $15 \mathrm{~s}$ at $10000 \mathrm{rpm}$ to wash the spin column membrane. The flow-through was discarded and the collection tube reused. $500 \mu \mathrm{l}$ buffer RPE was added and centrifuged $15 \mathrm{~s}$ at $10000 \mathrm{rpm}$ and the flow-through discarded. $500 \mu \mathrm{l}$ buffer RPE was added again and centrifuged $2 \mathrm{~min}$ at $10000 \mathrm{rpm}$, the flow-through then discarded. The spin column was placed in a new $1.5 \mathrm{ml}$ tube and $50 \mu \mathrm{l}$ RNase free water directly added to the membrane then Centrifuged $1 \mathrm{~min}$ at $10000 \mathrm{rpm}$. Final eluate contains purified RNA. RNA isolated from host plants was used in molecular analysis. RNA was quantified and applied in RNA Stable (Biomatrica). A spectrophotometer NanoDrop 2000 (Thermo Fisher Scientific, Waltham, MA, USA) was used to measure total RNA concentration and purity. To check the integrity of the total RNA, we used the Biological analyzer Agilent 2100 (Agilent, Santa Clara, CA, USA). Eleven mRNA-seq libraries were prepared at the BeCA-ILRI using the Illumina TruSeq Stranded mRNA Library preparation kit (Illumina, San Diego, CA, USA) following the manufacturer's instructions. Libraries were pooled for multiplexed sequencing using an Illumina MiSeq System to generate single end (SE) reads of $50 \mathrm{nt}$. Trimmed reads were used for de novo assembly and contigs aligned to the viral genomes database (ftp://ftp.ncbi.nih.gov/genomes/Viruses/all.fna.tar.gz/,

downloaded on October 2017) using CLC Genomics Workbench 10.1.2. The assembled contigs were subjected to a BLASTn search against the GenBank database [22]. Complete and partial BCMNV sequences used for comparison and phylogenetic analyses were retrieved from GenBank (http://www.ncbi.nlm.nih.gov/). Phylogenetic analyses and comparisons were performed using the MEGA v. 7 [23] and Dna SP v. 5 programs [24]. 


\section{Results and Discussion}

The BCMNV genome of isolate BCMNV KG12 has 9627 nucleotides. The sequence has been deposited in DNA Data Bank of Japan (DDBJ) database with accession number (LC493096.1) The Kenyan isolate of BCMNV is similar to that of other potyviruses [25]. During BLASTn search, The BCMNV KG12 isolate sequence was 94 - 99\% identical to 11 BCMNV complete genomes obtained from the Genbank and therefore show a close evolutionary relationship. The comparison of this Kenyan isolate with eleven complete genomes from the GenBank shows a small variation of less than $10 \%$.

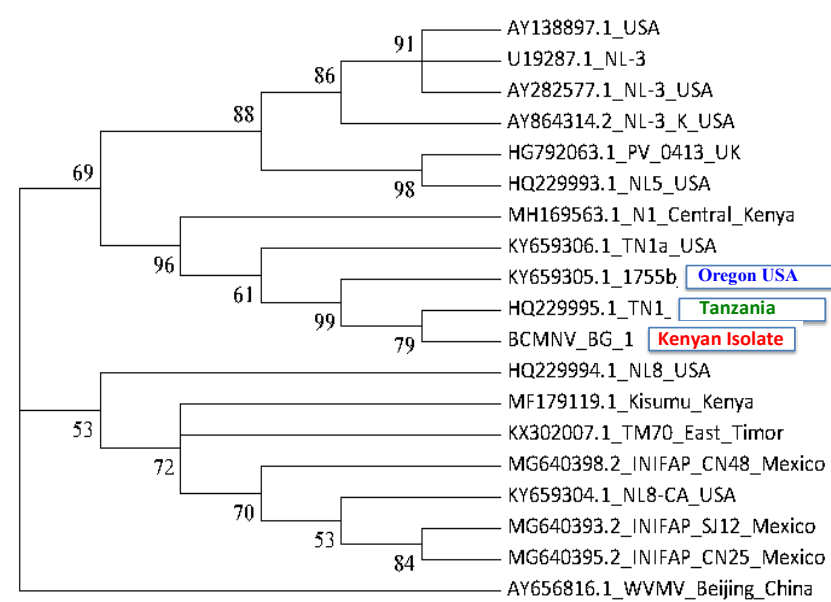

Figure 1. A maximum likelihood phylogenetic tree of $B C M N V$ isolate $B C M N V$ BG2. Generated using Mega 7 (Tamura-Nei default settings) from the alignment of seventeen full-length genomic sequences for BCMNV and an outgroup Wisteria vein mosaic virus (WVMV).

Phylogenetic analysis of BCMNV BG 12 isolate nucleotide sequences conducted using MEGA7 and the maximum likelihood algorithm to investigate the relationship between the isolate and 18 other BCMNV sequences in the GenBank as of October 2018 (Figure 1) placed BCMNV BG 12 isolate alongside an isolate from Oregon and that from Tanzania. This is an indication that the three isolates are closely related and all belong to strain TN-1 (Tanzania). This can only be possible if the Oregon isolate was either taken from East Africa or the East African ones came from there most likely in bean or other legume seeds for planting. The coverage of sequence using the conventional methods such as PCR succeeded by Sanger sequencing is relatively low and the technique is time consuming while NGS approaches give out numerous reads that are large enough to detect the target virus's quasi-species. Moreover, prior knowledge of the virus sequence is not to reveal the sequence of a virus or viroid, which hitherto may have not been known. Hence, several studies associated with virus and viroid quasi-species, prefer to use diverse NGS techniques instead of those based on the conventional PCR [26].

\section{Conclusion}

Symptoms of BCMNV are indistinguishable from other viruses in the field especially in western Kenya. Molecular detection for BCMNV being (+) ssRNA genome requires extraction of total RNA. The detection of BCMNV from samples together with information on bean varieties is important to define actions necessary to manage the virus in western Kenya. The application of next-generation sequencing forms a very efficient method in detection of plant viruses. Identification of viral RNA genomes in infected plant material by NGS is possible through the extraction and sequencing of total RNA or double stranded RNA. Diversity of BCMNV is less varied even with the geographical distance. This knowledge of BCMNV strain spectrum in Kenya is an important pre-requisite in exploitation of disease management through host resistance, which is the only durable and economic method of managing Bean common mosaic disease.

\section{Acknowledgements}

This work was funded by the National Research Fund, Kenya. We are grateful to Dr. Sue Jones and Godfrey Wokosiki for training and bioinformatics analysis, and BeCA-ILRI, Kenya for sequencing isolates.

\section{References}

[1] ICTV. (2013). Virus taxonomy: 2013 release. http://www.ictvonline.org/virusTaxonomy.asp.

[2] Singh, S. P., \& Schwartz, H. F. (2010). Breeding common bean for resistance to diseases: a review. Crop Science, 50, 21992223.

[3] Ivanov, K. I., Eskelin, K., Lo`hmus, A., \& Ma“kinen, K. (2014). Molecular and cellular mechanisms underlying potyvirus infection. Journal of General Virology, 95, 1415-1429.

[4] El-Sawy, M. A., Mohamed, H. A. E., \& Elsharkawy, M. M. (2013). Serological and molecular characterisations of the Egyptian isolate of Bean common mosaic virus. Archives of Phytopathology and Plant Protection, 47, 1-13.

[5] Rajama“ ki, M., Ma“ ki-Valkama, T., Ma“ kinen, K. \& Valkonen, J. P. T. (2004). Infection with potyviruses. In Plant-Pathogen Interactions, pp. 68-91. Edited by N. Talbot. Oxford: Blackwell.

[6] Chung, B. Y., Miller, W. A., Atkins, J. F. \& Firth, A. E. (2008). An overlapping essential gene in the Potyviridae. Proc Natl Acad Sci U S A 105, 5897-5902. Melgarejo, T. A., Lehtonen, M. T., Fribourg, C. E., Ränna"li, M and Valkonen, J. P. T. (2007). Strains of BCMV and BCMNV characterized from lima bean plants affected by deforming mosaic disease in Peru. Arch Virol. 152, 1941-1949.

[7] Morales, F. J and Bos, L. (1988). Descriptions of plant viruses: Bean common mosaic virus. DPV337. Wellesbourne UK: Association of Applied Biologists.

[8] Drijfhout, E. (1978). Genetic interaction between Phaseolus vulgaris and bean common mosaic virus with implications for strain identification and breeding for resistance. Pudoc, Wageningen: Agricultural Research Reports. 
[9] Vetten, H., Lesemann, D.-E and Maiss, E. (1992). Serotype A and $\mathrm{B}$ strains of bean common mosaic virus are two distinct potyviruses. Archives of Virology, 5, 415-431.

[10] Berger, P., Wyatt, S., Shiel, P., Silbernagel, M., Druffel, K., \& Mink, G. I. (1997). Phylogenetic analysis of the Potyviridae with emphasis on legume-infecting potyviruses. Archives of Virology, 142, 1979-1999.

[11] Mink G. I., Silbernagel M. J. (1992) Serological and biological relationships among viruses in the bean common mosaic virus subgroup. In: Barnett O. W. (eds) Potyvirus Taxonomy. Archives of Virology (Supplementum 5), vol 5. Springer, Vienna.

[12] Hu, J., Ferreria, S., Wang, M., Borth, W., Mink, G. I., \& Jordan, R. (1995). Purification, host range, serology, and partial sequencing of Dendrobium mosaic potyvirus, a new member of the Bean common mosaic virus subgroup. Phytopathology, 85 , 542-546.

[13] Worrall, E. A., Wamonje, F. O., Mukeshimana, G., Harvey, J. J. W., Carr J. P and Mitter, N. (2015). Bean Common Mosaic Virus and Bean Common Mosaic Necrosis Virus: Relationships, Biology, and Prospects for Control. Advances in Virus Research, 93: 1-46.

[14] Sharma, P., Sharma, P. N., Kapil, R., Sharma, S. K., \& Sharma, O. P. (2011). Analysis of 3'-terminal region of Bean common mosaic virus strains infecting common bean in India. Indian Journal of Virology, 22, 37-43.

[15] Melgarejo, T., Lehtonen, M., Fribourg, C., Ra“nna“li, M., \& Valkonen, J. P. T. (2007). Strains of BCMV and BCMNV characterized from Lima bean plants affected by deforming mosaic disease in Peru. Archives of Virology, 152, 1941-1949.

[16] Zitter, T. A. (1984). Virus diseases of snap and dry beans. Cooperative extension, New York state. Department of plant pathology, Cornell University. 729 (30).

[17] Omunyin, M. E., Gathuru, E. M., Mukunya, D. M. (1995). Pathogenicity groups of Bean common mosaic virus isolates in Kenya. Plant Disease 79: 985-989.
[18] Morales, J. F. (1983). El mosaico común del frijol: metodología de investigación y técnicas de control. Ed. revisada. CIAT, Cali. Colombia. 26.

[19] Udayashankar, A. C, Chandra Nayaka, S, Niranjana. S. R, Mortense C. N. and Prakash H. S. (2012). Immunocapture RT-PCR detection of Bean common mosaic virus and strain blackeye cowpea mosaic in common bean and black gram in India. Archives of Phytopathologyand Plant Protection Vol. 45 , No. 13, August 2012, 1509-1518.

[20] Drijfhout, E and Morales FJ. (2005). Bean mosaic virus. In: Schwartz H, Steadman JR, Hall R, Foster RL, editors. Compendium of bean diseases. 2nd ed. St. Paul (USA): APS Press p. 63-64.

[21] Morales, F. J., and Castaño, M. (2008). Enfermedades virales del frijol común en América Latina. Centro Internacional de Agricultura Tropical (CIAT). Palmira, Colombia.

[22] Camacho, C., Coulouris, G., Avagyan, V., Ma, N., Papadopoulos, J., Bealer, K and Madden, T. L. (2009). BLAST+: architecture and applications. BMC Bioinformatics 10, 421 doi: 10.1186/1471-2105-10-421.

[23] Kumar, S. Stecher1 G. and Tamura K. 2016. MEGA7: Molecular Evolutionary Genetics Analysis Version 7.0 for Bigger Datasets. [Mol Biol Evol. 2016] PMID: 27004904.

[24] Librado, P. and Rozas, J. 2009. DnaSP v5: a software for comprehensive analysis of DNA polymorphism data. Bioinformatics 25: 1451-1452.

[25] Altschul SF, Gish W, Miller W, Myers EW, Lipman DJ. 1990. Basic local alignment search tool. J Mol Biol 215: 403-410.

[26] Jo, Y., Choi, H., Kim, S.-M., Kim, S.-L., Lee, B. C., and Cho, W K. (2016). Integrated analyses using RNA-Seq data reveal viral genomes, single nucleotide variations, the phylogenetic relationship, and recombination for Apple stem grooving virus. BMC Genomics 17: 579. 